\title{
PENENTUAN LOKASI LUMBUNG PANGAN BERDASARKAN GRAVITY LOCATION MODELS DENGAN KOORDINAT UTM DI PROVINSI MALUKU UTARA
}

\author{
Nafisah Riskya Hasna ${ }^{1, *}$, Adi Setiawan ${ }^{1}$, Hanna Arini Parhusip ${ }^{1}$ \\ ${ }^{1}$ Jurusan Matematika, Fakultas Sains dan Matematika, Universitas Kristen Satya Wacana, Salatiga, Jawa \\ Tengah 50711 \\ *email korespondensi: nafisahriskya1996@gmail.com
}

\begin{abstract}
ABSTRAK
Salah satu usaha pemerintah dalam menyejahterakan masyarakat yaitu memenuhi kebutuhan pangan masyarakatnya. Pengendalian dalam penyediaan bahan pangan sangat diperlukan untuk dapat membantu dalam mengontrol distribusi bahan pangan. Dalam pengendalian penyediaan bahan pangan digunakan Gravity Location Models (GLM). GLM pada penelitian ini digunakan untuk menentukan suatu gudang yang berfungsi sebagai penghubung antara sumber-sumber pasokan dan beberapa lokasi sehingga dapat meminimalisasi biaya transportasi. Lokasi suatu gudang tersebut menggunakan koordinat geografis yang akan ditransformasikan ke koordinat UTM (Universal Transverse Mercator). Penelitian ini menggunakan data koordinat geografis pada Google Maps dan data jumlah penduduk, padi, jagung, dan ubi kayu Provinsi Maluku Utara Tahun 2014. Pengolahan data dilakukan secara manual dan menggunakan metode grid untuk mencari koordinat lokasi gudang atau lumbung pangan. Hasil dari perhitungan menggunakan (1) rumus (38) dan (39) dan (2) metode grid adalah koordinat lokasi lumbung pangan yang memiliki biaya transportasi minimum di Provinsi Maluku Utara yaitu terletak pada Kabupaten Halmahera Timur.
\end{abstract}

Kata-kata kunci: biaya transportasi; distribusi bahan pangan; Gravity Location Models; koordinat UTM; lokasi lumbung pangan

\section{PENDAHULUAN}

Provinsi Maluku Utara merupakan provinsi yang memiliki 8 kabupaten dan 2 kota dimana masingmasing kabupaten dan kota dengan memiliki kepadatan penduduk yang berbeda-beda. Oleh karena itu, kebutuhan dan produksi pangan masing-masing daerah berbeda pula. Sektor yang dominan di Maluku Utara yaitu sektor pertanian akan tetapi kebutuhan beras di Maluku Utara banyak dipenuhi dari luar daerah dikarenakan produksi beras masih kurang untuk memenuhi kebutuhan masyarakat Maluku Utara sedangkan kebutuhan pangan yang lain seperti jagung dan ubi-ubian masih bisa memenuhi kebutuhan masyarakat Maluku Utara sehingga penduduk harus menanggung mahalnya biaya transportasi untuk distribusi bahan pangan ke daerah tersebut.

Hal ini akan berbeda jika bahan pangan tersebut dapat dihasilkan dari hasil budidaya mandiri tanpa harus mendatangkan bahan pangan dari daerah lain (BPPN, 2015). Permasalahan tersebut dikarenakan kondisi Maluku Utara yang dominan lautan sehingga sarana prasarana transportasi dan komunikasi masih menjadi kendala dalam memenuhi kebutuhan pangan.

Oleh karena itu, penelitian ini bertujuan untuk menentukan lokasi optimal lumbung pangan yang belum ada di provinsi Maluku Utara. Model yang digunakan adalah Gravity Location Models (GLM). Keunggulan GLM yaitu dapat menentukan lokasi suatu fasilitas yang menjadi penghubung antara sumbersumber pasokan dan beberapa lokasi pasar dan dapat menganalisis biaya transportasi yang bisa dikurangi sehingga dapat mendistribusikan bahan pangan secara merata tanpa menyebabkan stok bahan pangan di suatu daerah akan kelebihan sedangkan di daerah lain menjadi kekurangan.

Berkaitan dengan upaya meminimumkan biaya transportasi untuk mendistribusikan bahan pangan, GLM didasarkan pada pemilihan koordinat titik suatu pusat distribusi yang memberikan jarak total terpendek terhadap keseluruhan pusat zona produksi yang harus dipasok. Suatu titik yang dinyatakan dengan koordinat (dua dimensi atau tiga dimensi) mengacu pada sistem koordinat yang didefinisikan sebagai berikut: (1) lokasi titik asal (titik nol) dari sistem koordinat; (2) orientasi dari sumbu-sumbu koordinat; (3) besaran (kartesian, curviliner) yang digunakan untuk mendefinisikan posisi suatu titik dalam sistem koordinat tersebut (Abidin, 2001). 
Sistem koordinat proyeksi yang lazim digunakan di Indonesia yaitu Sistem Koordinat Geografis dan Universal Transverse Mercator (UTM). Proyeksi koordinat UTM menentukan bagaimana objek-objek di permukaan bumi (yang sebenarnya tidak datar) dipindahkan atau diproyeksikan pada permukaan peta yang berupa bidang datar (Wartika dan Ghoni, 2013). Penelitian ini awalnya akan memakai sistem koordinat geografis yang kemudian akan diproyeksikan ke sistem koordinat UTM. Pada penelitian ini bahan pangan yang diamati adalah padi jagung dan ubi kayu, sedangkan koordinat geografis yang diamati hanya daerah yang berada pada belahan utara garis katulistiwa yaitu menggunakan 7 dari 10 Kabupaten/Kota yang ada di Provinsi Maluku Utara.

Berikut ini penelitian yang mengkaji tentang penentuan lokasi gudang atau pabrik yaitu Ama dkk (2015) yang menentukan lokasi lumbung pangan di Kabupaten Minahasa Tenggara dengan menggunakan koordinat geografis yaitu Latitude dan Longitude tanpa mentransformasikan ke koordinat UTM. Kemudian Rosita dkk (2010) yang mengukur performansi pergerakan barang yang akan dipasarkan di outlet ritel modern (pasar modern) dengan penambahan pusat distribusi dan penggunaan infrastruktur jalan tol sebagai jalur alternatif pengiriman barang. Yang ketiga yaitu Yunitasari yaang menentukan lokasi gudang lokal PT. ABC di daerah Depok, Kalasan, Berbah, Ngaglik, Ngemplak, dan Cangkringan dengan menggunakan metode GLM. Yang keempat yaitu Patrisina dkk (2011) mengkaji analisis kelayakan pendirian distribution centre dari segi aspek teknis dan keuangan untuk mengkoordinasikan kegiatan antar produsen dan konsumen OVOP Sulaman/Bordir dalam konsep manajemen rantai pasok dengan kriteria minimasi total ongkos sistem keseluruhan.

Dari hasil penelitian diatas, terdapat persamaan dan perbedaan dengan penelitian sebelumnya. Persamaannya yaitu topik penelitian berdasarkan metode Gravity Location Models sedangkan perbedaannya yaitu obyek penelitian serta pengembangan metode.

\section{DASAR TEORI, METODE, DAN DATA PENELITIAN}

\section{Sistem Koordinat}

Sistem koordinat adalah sekumpulan aturan yang menentukan bagaimana koordinat-koordinat yang bersangkutan merepresentasikan titik-titik. Aturan ini biasanya mendefinisikan titik asal serta beberapa sumbu koordinat yang digunakan untuk mengukur jarak dan sudut sehingga menghasilkan koordinat (Wartika dan Ghoni, 2013). Sistem koordinat yang lazim digunakan di Indonesia yaitu (Snyder, 1926):

1. Sistem Koordinat Geografis; digunakan untuk menggambarkan keadaan global dimana satuan unit yang digunakan adalah degree (derajat atau ${ }^{\circ}$ ). Sistem koordinat ini memiliki beberapa komponen yaitu Lintang (Latitude) yang merupakan lingkaran Equator dihitung ke Utara (Lintang Utara) dan ke Selatan (Lintang Selatan) dan Bujur (Longitude) dimana Bujur $0^{\circ}$ terletak di GREENWICH di negara Inggris dihitung ke Barat (Bujur Barat) dan ke Timur (Bujur Timur).

2. Sistem Koordinat UTM; menyatakan proyeksi yang lebih detail dan bersifat lokal untuk kita gunakan dan satuan unit yang digunakan adalah meter. Pada sistem koordinat ini dunia dibagi dalam zona-zona dengan jumlah 60 zona dengan interval $6^{\circ}$ dimana zona 1 sampai zona 60 berawal dari Bujur $180^{\circ}$ (Zona 1) ke timur kemudian melewati Bujur $0^{\circ}$ (Zona 30) berakhir di Bujur $180^{\circ}$ (Zona 60).

\section{Proyeksi Peta}

Proyeksi peta adalah metode penyajian permukaan bumi pada suatu bidang datar dari sistem koordinat geografis. Permukaan bumi fisis tidak teratur sehingga dipilih suatu bidang yang teratur mendekati bidang fisis bumi yaitu bidang ellipsoid. Bidang tersebut merupakan suatu bidang lengkung yang dapat digunakan sebagai bidang referensi hitungan untuk menyatakan posisi titik-titik di atas permukaan bumi dalam suatu sistem koordinat geografis, yaitu Lintang $(\Phi)$ dan Bujur $(\lambda)$ (Prihandito, 1998).

\section{Transformasi Koordinat Geografis ke Koordinat UTM}

Transformasi koordinat titik dari sistem koordinat geografis ke sistem koordinat UTM menggunakan definisi berikut (Hager et al., 1986):

$a=$ semi-major axis of the ellipsoid (sumbu semi utama pada ellipsoid)

$=6378137$, 
$b=$ semi-minor axis of the ellipsoid (sumbu semi minor pada ellipsoid)

$=6356752.314245$,

$\varphi=$ latitude (lintang),

$\lambda=$ longitude (bujur),

$f=$ flattening $($ penggepengan $)=\frac{a-b}{a}$

$e^{2}=(\text { first eccentricity })^{2}=(\text { eksentrisitas pertama })^{2}=\frac{a^{2}-b^{2}}{a^{2}}$

$e^{, 2}=(\text { second eccentricity })^{2}=(\text { eksentrisitas kedua })^{2}=\frac{a^{2}-b^{2}}{b^{2}}$

$n=\frac{a-b}{a+b}=\frac{f}{2-f}$

$\rho=$ radius of curvature in the meridian (jari - jari kelengkungan pada meridian)

$\rho=\frac{a\left(1-e^{2}\right)}{\left(1-e^{2} \sin ^{2} \Phi\right)}$

$v=$ radius of curvature in the prime vertical; also defined as the normal to the ellipsoid terminating at the minor axis

$v=\frac{a}{\left(1-e^{2} \sin ^{2} \Phi\right)^{1 / 2}}$

$S=$ meridional arc, the true meridional distance on the ellipsoid from the equator

$S=A \Phi-B \sin 2 \Phi+C \sin 4 \Phi-D \sin 6 \Phi+E \sin 8 \Phi$

dengan:

$A=a\left[1-n+\frac{5}{4}\left(n^{2}-n^{3}\right)+\frac{81}{64}\left(n^{4}-n^{5}\right)+\cdots\right]$

$B=\frac{3}{2} a\left[n-n^{2}+\frac{7}{8}\left(n^{3}-n^{4}\right)+\frac{55}{64} n^{5}+\cdots\right]$

$C=\frac{15}{16} a\left[n^{2}-n^{3}+\frac{3}{4}\left(n^{4}-n^{5}\right)+\cdots\right]$

$D=\frac{35}{48} a\left[n^{3}-n^{4}+\frac{11}{16} n^{5}+\cdots\right]$

$E=\frac{315}{512} a\left[n^{4}-n^{5}+\cdots\right]$

$\lambda_{0}=$ longitude of the origin (the central meridian)

$\Delta \lambda=\lambda-\lambda_{0}$

$k_{0}=$ central scale factor (faktor skala pusat) $=0.9996$

$k=$ faktor skala

$F N=$ False Northing $(0$ untuk belahan bumi utara;

10000000 untuk belahan bumi selatan)

$F E=$ False Easting (500000)

$E=$ grid easting

$N=$ grid northing

$C=$ convergence of the meridians (konvergensi meridian) 


$$
\begin{aligned}
T 1= & S k_{0} \\
T 2= & \frac{v \sin \Phi \cos \Phi k_{0}}{2} \\
T 3= & \frac{v \sin \Phi \cos ^{3} \Phi k_{0}}{24}\left(5-\tan ^{2} \Phi+9 e^{\prime 2} \cos ^{2} \Phi+4 e^{\prime 4} \cos ^{4} \Phi\right) \\
T 4= & \frac{v \sin \Phi \cos ^{5} \Phi k_{0}}{720}\left(61-58 \tan ^{2} \Phi+\tan ^{4} \Phi+270 e^{2} \cos ^{2} \Phi\right. \\
& -330 \tan ^{2} \Phi e^{\prime 2} \cos ^{2} \Phi+445 e^{\prime 4} \cos ^{4} \Phi+324 e^{\prime 6} \cos ^{6} \Phi \\
& -680 \tan ^{2} \Phi e^{\prime 4} \cos ^{4} \Phi+88 e^{\prime 8} \cos ^{8} \Phi-600 \tan ^{2} \Phi e^{\prime 5} \cos ^{6} \Phi \\
& -192 \tan ^{2} \Phi e^{\prime 8} \cos ^{8} \Phi \\
T 5= & \frac{v \sin \Phi \cos ^{7} \Phi k_{0}}{40320}\left(1385-3111 \tan ^{2} \Phi+543 \tan ^{4} \Phi-\tan ^{6} \Phi\right) \\
T 6= & v \cos ^{6} \Phi k_{0} \\
T 7= & \frac{v \cos ^{3} \Phi k_{0}}{6}\left(1-\tan ^{2} \Phi+e^{2} \cos ^{2} \Phi\right) \\
T 8= & \frac{v \cos ^{5} \Phi k_{0}}{120}\left(5-18 \tan ^{2} \Phi+\tan ^{4} \Phi+14 e^{\prime 2} \cos ^{2} \Phi\right. \\
& -58 \tan ^{2} \Phi e^{\prime 2} \cos ^{2} \Phi+13 e^{4} \cos ^{4} \Phi+4 e^{66} \cos ^{6} \Phi \\
& -64 \tan ^{2} \Phi e^{\prime 4} \cos ^{4} \Phi-24 \tan ^{2} \Phi e^{6} \cos ^{6} \Phi \\
T 9= & \frac{v \cos ^{7} \Phi k_{0}}{5040}\left(61-479 \tan ^{2} \Phi+179 \tan ^{4}-\tan ^{6} \Phi\right)
\end{aligned}
$$

Sehingga dapat dihitung untuk mencari $E$ dan $N$ dengan rumus sebagai berikut:

$$
\begin{aligned}
& N=F N+\left(T 1+(\Delta \lambda)^{2} T 2+(\Delta \lambda)^{4} T 3+(\Delta \lambda)^{6} T 4+(\Delta \lambda)^{8} T 5\right) \\
& E=F E+\left(\Delta \lambda T 6+(\Delta \lambda)^{3} T 7+(\Delta \lambda)^{5} T 8+(\Delta \lambda)^{7} T 9\right)
\end{aligned}
$$

Contoh:

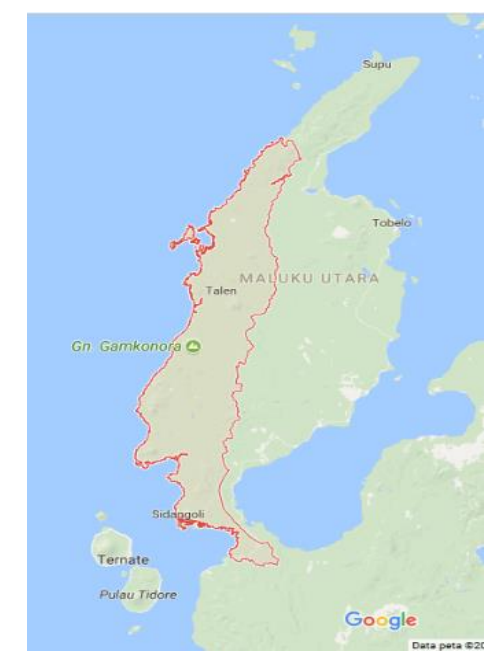

Gambar 1. Peta Kabupaten Halmahera Barat Provinsi Maluku Utara.

Diberikan suatu titik koordinat geografis pada Ibukota Kabupaten Halmahera Barat Provinsi Maluku Utara yaitu $(\Phi, \lambda)=(1.080430,127.480162)$. Koordinat tersebut akan ditransformasikan ke koordinat UTM berdasarkan persamaan (1) sampai (19). Hasil transformasi untuk koordinat UTM yaitu Easting $=330890$ E dan Northing $=119462.4 \mathrm{~N}$ dengan zona 52 


\section{Transformasi UTM Geografis ke Koordinat Geografis}

Transformasi koordinat titik dari sistem koordinat UTM ke sistem koordinat Geografis menggunakan definisi berikut (Hager et al., 1986):

$M=0$

$M=M_{0}+\frac{N}{k_{0}}$

$e_{1}=\frac{\left[1-\left(1-e^{2}\right)^{\frac{1}{2}}\right]}{\left[1+\left(1-e^{2}\right)^{\frac{1}{2}}\right]}$

$\mu=\frac{M}{\left[\alpha\left(1-\frac{e^{2}}{4}-\frac{3 e^{4}}{64}-\frac{5 e^{6}}{256}-\cdots\right)\right]}$

$\Phi^{\prime}=\mu+\sin 2 \mu\left(\frac{3}{2} e_{1}-\frac{27}{32} e_{1}^{3}+\cdots\right)+\sin 4 \mu\left(\frac{21}{16} e_{1}^{2}-\frac{55}{32} e_{1}^{4}+\cdots\right)$

$+\sin 6 \mu\left(\frac{151}{96} e_{1}^{3}+\cdots\right)+\sin 8 \mu\left(\frac{1097}{512} e_{1}^{4}-\cdots\right)+\cdots$

$\Delta E=E-F E$

$T 10=\frac{\tan \Phi^{\prime}}{2 \rho v k_{0}^{2}}$

$T 11=\frac{\tan \Phi^{\prime}}{24 \rho v^{3} k_{0}^{4}}\left(5+3 \tan ^{2} \Phi^{\prime}+e^{\prime 2} \cos ^{2} \Phi^{\prime}-4 e^{\prime 4} \cos ^{4} \Phi^{\prime}\right.$

$\left.-9 \tan ^{2} \Phi^{\prime} \mathrm{e}^{\prime 2} \cos ^{2} \Phi^{\prime}\right)$

$T 12=\frac{\tan \Phi^{\prime}}{720 \rho v^{5} k_{0}^{5}}\left(61+90 \tan ^{2} \Phi^{\prime}+46 e^{2} \cos ^{2} \Phi^{\prime}+45 \tan ^{4} \Phi^{\prime}\right.$

$-252 \tan ^{2} \Phi^{\prime} \mathrm{e}^{\prime 2} \cos ^{2} \Phi^{\prime}-3 \mathrm{e}^{\prime 4} \cos ^{4} \Phi^{\prime}+100 \mathrm{e}^{6} \cos ^{6} \Phi^{\prime}$

$-66 \tan ^{2} \Phi^{\prime} e^{\prime 4} \cos ^{4} \Phi^{\prime}-90 \tan ^{4} \Phi^{\prime} e^{\prime 2} \cos ^{2} \Phi^{\prime}+88 e^{\prime 8} \cos ^{8} \Phi^{\prime}$

$\left.+225 \tan ^{4} \Phi^{\prime} e^{\prime 4} \cos ^{4} \Phi^{\prime}+84 \tan ^{2} \Phi^{\prime} e^{\prime 6} \cos ^{6} \Phi^{\prime}-192 \tan ^{2} \Phi^{\prime} e^{\prime 8} \cos ^{8} \Phi^{\prime}\right)$

$T 13=\frac{\tan \Phi^{\prime}}{40320 \rho v^{7} k_{0}^{8}}\left(1385+3633 \tan ^{2} \Phi^{\prime}+4095 \tan ^{4} \Phi^{\prime}+1575 \tan ^{6} \Phi^{\prime}\right)$

$T 14=\frac{1}{v \cos \Phi^{\prime} k_{0}}$

$T 15=\frac{1}{6 v^{3} \cos \Phi^{\prime} k_{0}^{3}}\left(1+2 \tan ^{2} \Phi^{\prime}+e^{\prime 2} \cos ^{2} \Phi^{\prime}\right)$

$T 16=\frac{1}{120 v^{5} \cos \Phi^{\prime} k_{0}^{5}}\left(5+6 e^{\prime 2} \cos ^{2} \Phi^{\prime}+28 \tan ^{2} \Phi^{\prime}-3 e^{\prime 4} \cos ^{4} \Phi^{\prime}\right.$

$+8 \tan ^{2} \Phi^{\prime} e^{2} \cos ^{2} \Phi^{\prime}+24 \tan ^{4} \Phi^{\prime}-4 e^{\prime 6} \cos ^{6} \Phi^{\prime}$

$\left.+4 \tan ^{2} \Phi^{\prime} \mathrm{e}^{\prime 4} \cos ^{4} \Phi^{\prime}+24 \tan ^{2} \Phi^{\prime} \mathrm{e}^{\prime 6} \cos ^{6} \Phi^{\prime}\right)$

$T 17=\frac{1}{5040 v^{7} \cos \Phi^{\prime} k_{0}^{7}}\left(61+662 \tan ^{2} \Phi^{\prime}+1320 \tan ^{4} \Phi^{\prime}+720 \tan ^{6} \Phi^{\prime}\right)$

Sehingga dapat dihitung untuk mencari $\mathrm{E}$ dan $\mathrm{N}$ dengan rumus sebagai berikut:

$\Phi=\Phi^{\prime}-(\Delta E)^{2} T 10+(\Delta E)^{4} T 11-(\Delta E)^{6} T 12+(\Delta E)^{8} T 13$

$\lambda=\lambda_{0}-\Delta E T 14+(\Delta E)^{3} T 15-(\Delta E)^{5} T 16+(\Delta E)^{7} T 17$

Contoh:

Diberikan koordinat UTM dari Kabupaten Halmahera Barat Provinsi Maluku Utara yang sudah didapat pada Contoh 1 yaitu Easting $=330890$ E dan Northing $=119462.4 \mathrm{~N}$ dengan zona 52. Koordinat tersebut akan 
ditransformasikan ke koordinat geografis berdasarkan persamaan (20) sampai (35). Hasil transformasi untuk koordinat UTM yaitu Latitude $=1.084 \mathrm{LU}$ dan Longitude $=127.4802 \mathrm{BT}$.

\section{Gravity Location Models (GLM)}

Gravity Location Models (GLM) digunakan untuk menentukan lokasi suatu fasilitas (misalnya gudang atau pabrik) yang menjadi penghubung antara sumber-sumber pasokan dan beberapa lokasi. Jika fasilitas yang dimaksud adalah gudang maka gudang tersebut yang akan menjadi penyangga antara beberapa lokasi yang memproduksi barang dan beberapa lokasi pasar dimana produk-produk tersebut akan didistribusikan. GLM menggunakan beberapa asumsi yaitu (Achlaq, 2012):

1. Ongkos-ongkos transportasi diasumsikan naik secara linier sebanding dengan volume yang dipindahkan.

2. Sumber-sumber pasokan maupun pasar bisa ditentukan lokasinya pada suatu peta dengan koordinat $x$ dan $y$ yang jelas.

Perhitungan untuk banyaknya kebutuhan masing-masing daerah dan volume bahan pangan yang akan dipindahkan menggunakan rumus sebagai berikut:

$$
\begin{aligned}
& K=\frac{P . m \cdot T}{1000} \\
& V=c-K
\end{aligned}
$$

dengan:

$P \quad=$ Jumlah penduduk

$m \quad=$ Rata-rata konsumsi pangan $=0.3(\mathrm{~kg})$

$T \quad=$ Waktu $=365$ (hari)

$c \quad=$ Banyaknya produksi pangan (ton)

$K=$ Kebutuhan bahan pangan suatu daerah (ton per hari)

Selanjutnya dapat dihitung koordinat lokasi menggunakan rumus sebagai berikut:

$$
\begin{gathered}
x=\frac{\sum_{n=1}^{k} V_{i} X_{i}}{\sum_{n=1}^{k} V_{i}}=\frac{V_{1} X_{1}+V_{2} X_{2}+\cdots+V_{k} X_{k}}{V_{1}+V_{2}+\cdots+V_{k}} \\
y=\frac{\sum_{\mathrm{n}=1}^{\mathrm{k}} \mathrm{V}_{\mathrm{i}} \mathrm{Y}_{\mathrm{i}}}{\sum_{\mathrm{n}=1}^{\mathrm{k}} \mathrm{V}_{\mathrm{i}}}=\frac{\mathrm{V}_{1} \mathrm{Y}_{1}+\mathrm{V}_{2} \mathrm{Y}_{2}+\cdots+\mathrm{V}_{\mathrm{k}} \mathrm{Y}_{\mathrm{k}}}{\mathrm{V}_{1}+\mathrm{V}_{2}+\cdots+\mathrm{V}_{\mathrm{k}}}
\end{gathered}
$$

dengan:

$x=$ Koordinat lokasi yang dihasilkan pada sumbu $x$,

$y=$ Koordinat lokasi yang dihasilkan pada sumbu $y$,

$\mathrm{k}$ = Banyaknya kabupaten/kota,

$V_{i}=$ Beban produksi yang akan dipindahkan dari gudang ke lokasi sumber pasokan.

Proses perhitungan jarak antara dua lokasi pada model ini yang dihitung sebagai jarak geometris antara dua lokasi menggunakan rumus sebagai berikut (Ama dkk, 2015):

$$
F_{n}=\sqrt{\left(x-x_{n}\right)^{2}+\left(y-y_{n}\right)^{2}}
$$

dengan $\left(x_{n} ; y_{n}\right)$ adalah kandidat koordinat lokasi sumber pasokan dan $(x, y)$ adalah fasilitas yang dipertimbangkan.

Rumus untuk mendapatkan lokasi lumbung pangan yang meminimumkan biaya transportasi sebagai berikut [9]:

$$
T C=\sum_{n=1}^{k} d_{n} V_{n} F_{n}
$$

dengan :

$d_{n}=$ Biaya transportasi per unit beban per kilometer antara kandidat lokasi fasilitas dengan lokasi sumber pasokan,

$\mathrm{V}_{\mathrm{n}}=$ Beban yang akan dipindahkan antara fasilitas dengan lokasi sumber pasokan,

$\mathrm{F}_{\mathrm{n}}=$ Jarak antara lokasi fasilitas dengan sumber pasokan ke-n. 


\section{Data Penelitian}

Pengumpulan data dilakukan dengan cara menentukan lokasi dari dari koordinat geografis 7 kabupaten dari Google Maps untuk Provinsi Maluku Utara. Data yang diperoleh dari BPS (BPS, 2015) yaitu data hasil produksi padi, jagung, dan ubi kayu setiap kabupaten, jumlah penduduk setiap kabupaten, dan kebutuhan pangan setiap kabupaten dalam setahun dihitung untuk mendapatkan hasil ketersediaan pangan yang dimiliki untuk setiap kabupaten.

\section{Data Koordinat Geografis}

Dalam penentuan koordinat Geografis pada Google Maps, penulis menentukan berdasarkan kantor Bupati dan Walikota masing-masing daerah. Letak titik koordinat masing-masing daerah dapat dilihat pada Gambar 2 berikut :

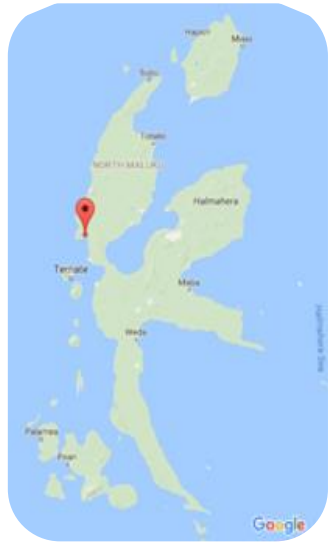

Halmahera Barat

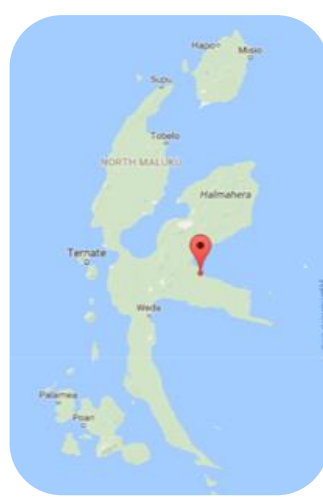

Halmahera Timur

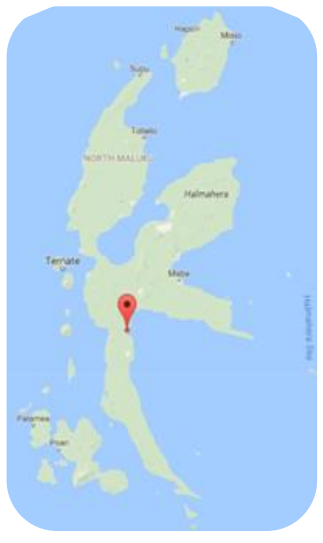

Halmahera Tengah

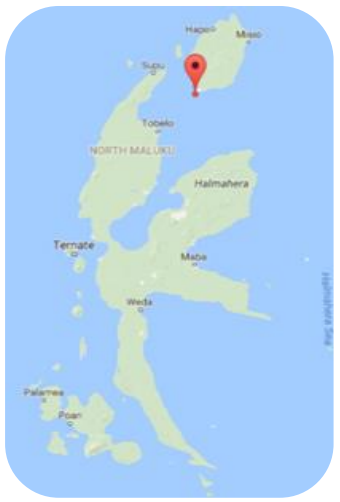

Pulau Morotai

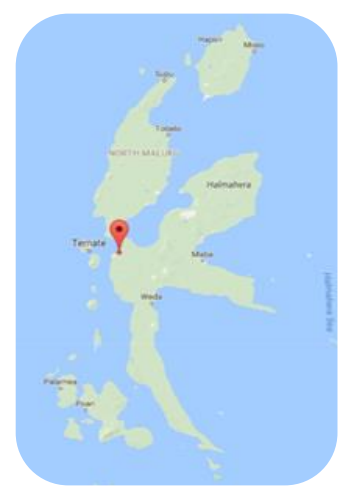

Tidore Kepulauan

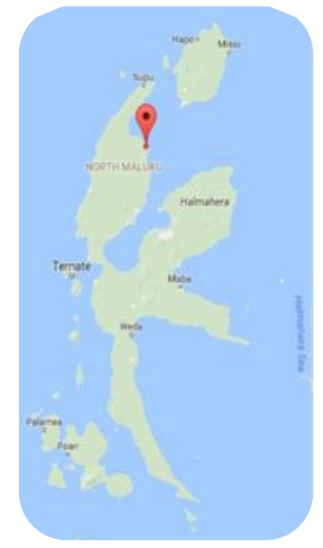

Halmahera Utara

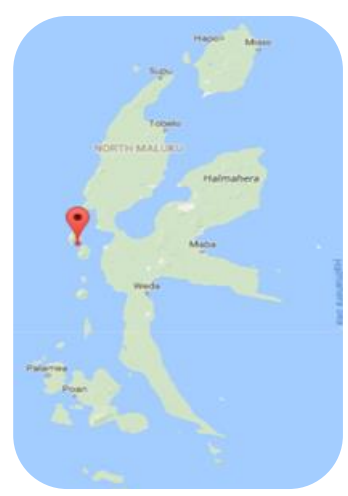

Ternate

Gambar 2. Titik koordinat geografis masing-masing kabupaten/kota. 


\section{Transformasi Koordinat}

Data koordinat geografis Provinsi Maluku Utara pada Google Maps ditransformasikan ke koordinat UTM dengan hasil pada Tabel 1.

Tabel 1. Hasil Transformasi Koordinat Geografis ke Koordinat UTM Masing-Masing Kabupaten/Kota di Provinsi Maluku Utara Tahun 2014.

\begin{tabular}{ccccc}
\hline Kabupaten/kota & Latitude & Longitude & Easting & Northing \\
\hline Halmahera Barat & 1.08 & 127.4 & 330890 & 119462.4 \\
Halmahera Tengah & 0.33 & 127.8 & 374281.1 & 36526.3 \\
Halmahera Utara & 1.72 & 127.9 & 387903.1 & 191044.1 \\
Halmahera Timur & 0.67 & 128.2 & 420331.9 & 74883.7 \\
Pulau Morotai & 2.01 & 128.2 & 420338.5 & 222546.2 \\
Ternate & 0.76 & 127.3 & 317846.4 & 84547.3 \\
Tidore Kepulauan & 0.75 & 127.6 & 345299.6 & 83568.7 \\
\hline
\end{tabular}

\section{Menghitung Kebutuhan Pangan}

Berdasarkan data yang diperoleh terdapat jumlah produksi masing-masing bahan pangan padi, jagung, dan ubi kayu sehingga dapat dihitung jumlah dari keseluruhan bahan pangan tersebut yang dapat dilihat pada Tabel 2.

Tabel 2. Hasil Penghitungan Kebutuhan Pangan

\begin{tabular}{ccccccc}
\hline Kabupaten/kota & $\begin{array}{c}\text { Jumlah } \\
\text { Penduduk }\end{array}$ & $\begin{array}{c}\text { Padi } \\
\text { (ton) }\end{array}$ & $\begin{array}{c}\text { Jagung } \\
\text { (ton) }\end{array}$ & $\begin{array}{c}\text { Ubi kayu } \\
\text { (ton) }\end{array}$ & $\begin{array}{c}\text { Jumlah } \\
\text { produksi (ton) }\end{array}$ & $\begin{array}{c}\text { Kebutuhan pangan } \\
\text { (ton/tahun) }\end{array}$ \\
\hline Halmahera Barat & 108769 & 7574 & 2288 & 12499 & 22361 & 11910.2 \\
Halmahera Tengah & 48414 & 7505 & 195 & 4108 & 11808 & 5301.3 \\
Halmahera Utara & 176573 & 14900 & 4667 & 36880 & 56447 & 19334.7 \\
Halmahera Timur & 82914 & 26068 & 1427 & 14432 & 41927 & 9079.1 \\
$\quad$ Pulau Morotai & 59102 & 5401 & 1469 & 13856 & 20726 & 6471.6 \\
$\quad$ Ternate & 207789 & 0 & 189 & 1462 & 1651 & 22752.8 \\
Tidore Kepulauan & 95813 & 664 & 1303 & 8591 & 10558 & 10491.5 \\
\hline
\end{tabular}

\section{Menghitung Menggunakan Gravity Location Models}

Tabel 3. Data perhitungan transformasi koordinat dan beban produksi 7 kabupaten.

\begin{tabular}{cccc}
\hline Kabupaten/kota & Easting $(\boldsymbol{x})$ & Northing $(\boldsymbol{y})$ & $\boldsymbol{V}$ \\
\hline Halmahera Barat & 330890 & 119462.4 & 10450.7945 \\
Halmahera Tengah & 374281.1 & 36526.3 & 6506.667 \\
Halmahera Utara & 387903.1 & 191044.1 & 37112.2565 \\
Halmahera Timur & 420331.9 & 74883.7 & 32847.917 \\
Pulau Morotai & 420338.5 & 222546.2 & 14254.331 \\
Ternate & 317846.4 & 84547.3 & -21101.8955 \\
Tidore Kepulauan & 345299.6 & 83568.7 & 66.4765 \\
\hline
\end{tabular}

Hasil perhitungan transformasi koordinat yang disajikan pada Tabel 3, Easting $(x)$ dan Northing (y) merupakan koordinat UTM masing-masing kabupaten, kolom $V$ merupakan beban produksi pangan yang berlebih. Dalam hal ini, Kota Ternate merupakan satu-satunya daerah yang kekurangan produksi bahan pangan sedangkan daerah yang lain memiliki produksi pangan yang berlebih. Penentuan lokasi lumbung pangan ditentukan berdasarkan lokasi dengan biaya transportasi yang minim, penentuan ini dilakukan dengan menghitung menggunakan rumus (38), (39), (40), dan (41) dimana $d_{\mathrm{n}}$ merupakan biaya transportasi yang diasumsikan sama setiap daerah dengan diberi nilai 1. Hasil perhitungan tersebut dimasukkan dalam bentuk grid yang dapat dilihat pada Tabel 4 dimana pada kolom merupakan Easting $(x)$ dan pada baris merupakan Easting $(x)$. 
Jurnal Sains dan Edukasi Sains, Vol.1, No.2, Agustus 2018: 7-16

Tabel 4. Hasil perhitungan lokasi lumbung pangan dalam bentuk grid

\begin{tabular}{cccccccc}
\hline \multicolumn{2}{c}{$\begin{array}{c}\text { Koordinat } \\
\text { UTM }\end{array}$} & $\mathbf{3 0 0 0 0 0}$ & $\mathbf{3 3 0 0 0 0}$ & $\mathbf{3 6 0 0 0 0}$ & $\mathbf{3 9 0 0 0 0}$ & $\mathbf{4 2 0 0 0 0}$ & $\mathbf{4 5 0 0 0 0}$ \\
\hline & $\mathbf{3 0 0 0 0}$ & 2.5866 & 2.0969 & 1.7515 & 1.5504 & 1.4935 & 1.5808 \\
& $\mathbf{6 5 0 0 0}$ & 1.9830 & 1.4933 & 1.1479 & 0.9468 & 0.8898 & 0.9772 \\
& $\mathbf{1 0 0 0 0 0}$ & 1.5757 & 1.0860 & 0.7406 & 0.5395 & 0.4826 & 0.5699 \\
Northing & $\mathbf{1 3 5 0 0 0}$ & 1.3647 & 0.8751 & 0.5297 & 0.3285 & 0.2716 & 0.3589 \\
$\left(.10^{15}\right)$ & $\mathbf{1 7 0 0 0 0}$ & 1.3501 & 0.8604 & 0.5150 & 0.3139 & 0.2570 & 0.3443 \\
& $\mathbf{2 0 5 0 0 0}$ & 1.5318 & 1.0422 & 0.6968 & 0.4956 & 0.4387 & 0.5260 \\
& $\mathbf{2 4 0 0 0 0}$ & 1.9099 & 1.4202 & 1.0748 & 0.8737 & 0.8167 & 0.9041 \\
\hline
\end{tabular}

Berdasarkan Tabel 4, penghitungan dengan bentuk grid dengan kisaran sebesar (30000;35000) dengan hasil terkecil yang diperoleh berada pada kolom 5 dan baris 5 dengan nilai $2.570 \times 10^{14}$ yang berada pada koordinat UTM yaitu Easting $=420000 \mathrm{E}$ dan Northing $=170000 \mathrm{~N}$ dengan zona 52 dan jika dipoyeksikan ke koordinat geografis menjadi 1.5379 LU dan 128.2808 BT. Untuk mendapatkan hasil yang akurat, penghitungan dilakukan kembali dengan bentuk grid dengan kisarannya diperkecil sebesar $(5000 ; 300)$ dengan hasil yang diperoleh dengan nilai terkecil yaitu $2.3873 \times 10^{14}$ yang berada pada koordinat UTM yaitu Easting $=415000 \mathrm{E}$ dan Northing $=156000 \mathrm{~N}$ dengan zona 52 dan jika diproyeksikan ke koordinat geografis menjadi 1.4113 LU dan 128.2359 BT.

Sedangkan menurut perhitungan menggunakan rumus (38) dan (39) hasil yang diperoleh dari perhitungan koordinat lokasi yaitu $x=416836.147 \mathrm{~N}$ dan $y=155106.3453 \mathrm{E}$ yang kemudian diproyeksikan ke koordinat geografis menjadi $x=1.403145 \mathrm{LU}$ dan $y=128.2523 \mathrm{BT}$. Berdasarkan perhitungan menggunakan grid dan rumus (38) dan (39), keduanya terletak Provinsi Halmahera Timur.

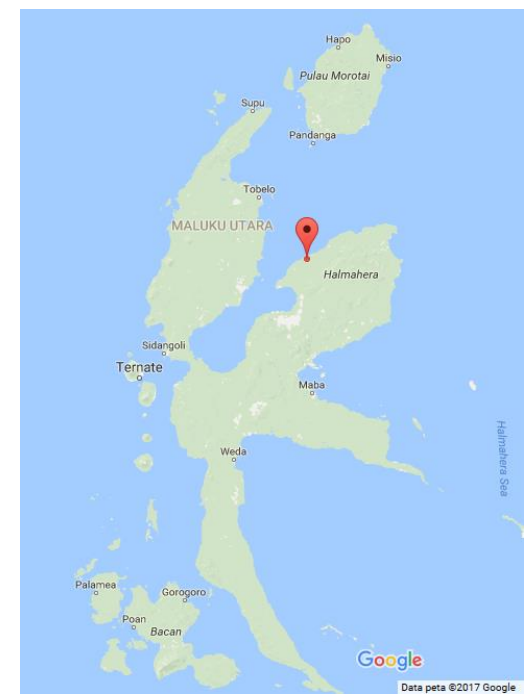

Gambar 3. Lokasi Lumbung Pangan dengan Biaya Transportasi yang Minim.

\section{SURVEI SINGKAT STUDI SEBELUMNYA}

Penelitian-penelitian lain yang terkait dengan penelitian ini adalah:

a. Penelitian yang dilakukan oleh Ama dkk (2015) yaitu menentukan lokasi lumbung pangan di Kabupaten Minahasa Tenggara dengan menggunakan koordinat geografis yaitu Latitude dan Longitude tanpa mentransformasikan ke koordinat UTM.

b. Penelitian yang dilakukan oleh Rosita dkk (2010) yaitu mengukur performansi pergerakan barang yang akan dipasarkan di outlet ritel modern (pasar modern) dengan penambahan pusat distribusi dan penggunaan infrastruktur jalan tol sebagai jalur alternatif pengiriman barang.

c. Penelitian yang dilakukan oleh Yunitasari (2015) yaitu menentukan lokasi gudang lokal PT. ABC di daerah Depok, Kalasan, Berbah, Ngaglik, Ngemplak, dan Cangkringan dengan menggunakan metode GLM. 
d. Penelitian yang dilakukan oleh Partisina dkk (2011) mengkaji analisis kelayakan pendirian distribution centre dari segi aspek teknis dan keuangan untuk mengkoordinasikan kegiatan antar produsen dan konsumen OVOP Sulaman/Bordir dalam konsep manajemen rantai pasok dengan kriteria minimasi total ongkos sistem keseluruhan.

\section{KESIMPULAN}

Berdasarkan hasil perhitungan dan pembahasan, perbandingan antara hasil menggunakan rumus (38) dan (39) dengan metode grid hanya selisih 0.008155 untuk lintang utara, sedangkan untuk bujur tinur hanya selisih 0.0164. Lokasi lumbung pangan untuk Provinsi Maluku Utara terletak pada Kabupaten Halmahera Timur. Penelitian ini dapat dikembangkan dengan memasukkan kabupaten/kota yang mempunyai 2 zona UTM.

\section{DAFTAR PUSTAKA}

Abidin, H. Z. 2001. Geodesi Satelit.

Achlaq, M. M. 2012. Merancang jaringan Supply Chain.

Ama, A. U. T., Sediyono, E., dan Setiawan, A. 2015. Rekayasa Algoritma Gravity Location Models untuk Penentuan Lokasi Lumbung Pangan Masyarakat Kabupaten Minahasa Tenggara. Jurnal Teknik Informatika dan Sistem Informasi, 1(3).

Badan Perencanaan Pembangunan Nasional. 2015. Seri Analisis Pembangunan Wilayah Provinsi Maluku Utara 2015. Sumber: http://bappeda.malutprov.go.id/ [16 Oktober 2017].

Badan Pusat Statistik. 2015. Maluku Utara Dalam Angka 2015. Sumber: https://malut.bps.go.id/ [16 Oktober 2017].

Hager, J. W., Behensky, J. F., and Drew, B. W. 1986. The Universal Grids: Universal Transverse Mercator (UTM) and Universal Polar Stereographic (UPS). Washington D. C.: Distribution Unlimited.

Partisina, R., dan Harma, B. 2011. Analisis Aspek Teknik dan Keuangan Pendirian Distribution Centre untuk Program One Village One Produck (OVOP) Studi Kasus: Sulaman/Bordir Agam. Jurnal IImiah Teknik Industri: Sumatera Barat.

Prihandito, A. 1998. Proyeksi Peta. Yogyakarta: Kanisius.

Rosita, M., Punjawan, I. N., dan Arvitrida, N. I 2010. Simulasi Sistem Logistik Perkotaan untuk Memenuhi Pasokan Barang ke Retail Modern di Surabaya dengan Penambahan Pusat Distribusi.

Snyder, J. P. 1926. Map Projections-A Working Manual. Washington: Library U. S. BUREAU OF MINES.

Wartika dan Ghoni, M. A. 2013. Sistem Informasi Geografis Jaringan Jalan Kabupaten Siak Provinsi Riau. Jurnal Ilmiah Program Studi Manajemen Informatika, 01.

Yunitasari, E. W. 2015. Metode Gravity Location Models dalam Penentuan Lokasi Cabang yang Optimal di PT. ABC. Tekinfo -- Jurnal Ilmiah Teknik Industri dan Informasi, 3(2): 75-82. 